DOI: https://doi.org/10.36502/2020/droa.6169

\title{
Income-Related Mortality by Diabetes Mellitus
}

Silva $\mathrm{AJL}^{1,2}$, Istilli $\mathrm{PT}^{1,2}$, Teixeira $\mathrm{CRS}^{1,2^{*}}$, Lima $\mathrm{RAD}^{1,2}$, Pereira MCA ${ }^{1,2}$, Damasceno $\mathrm{MMC}^{3}$, Garcia RAC ${ }^{2}$, Calixto AAS ${ }^{2}$

${ }^{1}$ Department of General and Specialized Nursing, University of Sao Paulo, Ribeirao Preto, Brazil

${ }^{2}$ Nursing School, University of Sao Paulo, Ribeirao Preto, Brazil

${ }^{3}$ Federal University of Ceara, Fortaleza, Brazil

Corresponding Author: Carla Regina de Souza Teixeira, Ph.D. ${ }^{\text {ORCID ID }}$

Address: Department of General and Specialized Nursing, Nursing School, University of Sao Paulo, Ribeirao Preto, Brazil; Tel: +55 16 3315300o; E-mail: carlarst@eerp.usp.br

Received date: 17 July 2020; Accepted date: 08 August 2020; Published date: 22 August 2020

Citation: Silva AJL, Istilli PT, Teixeira CRS, Lima RAD, Pereira MCA, Damasceno MMC, Garcia RAC, Calixto AAS. Income-Related Mortality by Diabetes Mellitus. Diab Res Open Access. 2020 Aug 22;2(2):56-63.

Copyright (C) 2020 Silva AJL, Istilli PT, Teixeira CRS, Lima RAD, Pereira MCA, Damasceno MMC, Garcia RAC, Calixto AAS. This is an open-access article distributed under the Creative Commons Attribution License, which permits unrestricted use, distribution, and reproduction in any medium, provided the original work is properly cited.

\section{Abstract}

This research aims to analyze income-related mortality by diabetes mellitus in a municipality inside the state of Sao Paulo, Brazil, from 2010 to 2014. It is about an ecological study and temporal tendency, it was analyzed, descriptively and spatially, the income-related deaths by diabetes mellitus from 2010 to 2014. There were 583 deaths, mostly (55.06\%) in sex female. It highlights, the negative spatial relation between the incomes of up to two minimum wages per capita and mortality rate by diabetes mellitus $(I=-0.13)$. The southern region was identified as a protection area $(\mathrm{RR}=0.39 ; 95 \% \mathrm{CI}=0.29-0.54)$ for the occurrence of mortality by diabetes mellitus in both sexes. It is hoped that the findings in this study may foster and guide prevention strategies, and health care advance for the low-income groups and residents in risk areas.

\section{Keywords}

Mortality, Diabetes Mellitus, Income, Spatial Analysis, Epidemiology

\section{Introduction}

Diabetes mellitus (DM) is one of four chronic noncommunicable diseases (CNCDs) group, which represents $71 \%$ overall deaths annually [1]. It is estimated that nearly 422 million people are DM carriers and thus most of them are residents of lowmedium income countries [1]. DM mortality and its complications account for $10.7 \%$ of overall deaths, exceeding infectious diseases such as HIV, tuberculosis, and malaria [2].

It stands out that, DM is responsible for multiples functional incapacities, affecting, not only the patient's physical independency, but also increases the need for family health care, moreover, it affects the country economic sector due to the loss of labor caused by retirements and premature deaths [3].

Another impact regarding the economy is the health care services overload, caused by the high number of admissions in hospitals of DM patients, primarily, related to disease chronification [4]. Moreover, there is a higher need for inputs for the treatment and its complications, increasing the length of hospital stay, thereby, increasing up to $19 \%$ of the treatment costs in comparison to a non-DM patient $[3,4]$.

In this way, it is worth noting the damages on the patient and the core family, coming from the need for lifestyle changes and adaptations, and thus results in 
a higher financial demand for the treatment and to have more healthy habits [5]. However, the emerged changes demanded a better lifestyle of a DM patient are linked to the social determinants of health, that is, where and how people live may impact positively or negatively on their healthiness [6]. Beyond that, the exposure in risk areas for the development of CNCDs, such as DM, or the opposite, in protected areas for the development of DM and others CNCDs, may affect the prevention on the complications or even cause the premature mortality among these different social groups $[2,6,7]$.

This study aims to investigate how the income can affect the quality of life, and mortality by DM, considering that such factors are directly associated with the access power on goods and services [6].

Considering the above, this study's goal is to analyze the bound between DM mortality and the income of a municipality inside the state of Sao Paulo, Brazil, from 2010 to 2014. It is hoped that this study may evidence the income impact on DM mortality.

\section{Methods}

This is an ecological study and applies temporal tendency [8], it took place in the county of Ribeirao Preto, located in the northeast region of Sao Paulo, 313 $\mathrm{km}$ from its Capital, in Brazil. The municipality comprises a total area of $650 \mathrm{Km}^{2}$ and it has a population of 604.682 inhabitants, according to 2010 census-based [9].

The study population was based on DM mortality data from 2010 to 2014, for which was provided by the Epidemiological Surveillance Division from Municipal Health Department of Ribeirao Preto, associated with the deaths of the residents in the urban area of the city and regardless the death site.

The data was settled by the following variables: sex (female or male), date, and cause of death. The death certificate and the DM ranking were taken as basic cause, according to $10^{\mathrm{a}}$ International Statistical Classification of Diseases and Related Health Problems (ICD-10), meaning, the matching DM classification E10 to E14 from ICD-10, where E10 includes type $1 \mathrm{DM}$;
E11, type 2 DM; E12, malnutrition-related DM; E13, other specified DM, and E14, unspecified DM [10].

The collected data was exported to an excel sheet software, in order to allow detailed treatment and further statistical analysis. In the first stage of analysis, it was picked out the registers of deaths of the residents of Ribeirao Preto, SP, Brazil, for inclusion, according to the municipality code.

The descriptive statistical analysis of the data was carried out, by using the Windows Stata Statistical Software version 14. In order to submit the descriptive data, it was drawn on the DM deaths frequency and proportion by year and sex from a long period ranging from 2010 to 2014.

The spatial data analysis started up with the geo codification of the DM deaths, performed by Google Earth online tool, to access the participant's residential address, where it showed their geographic coordinates, (latitude and longitude) and it was set out the cartographic base of Ribeirao Preto, SP, Brazil, which represents 1004 census sectors, it is 988 urban and 16 rural [9]. This step was provided by the software QGIS Desktop version 2.18.

Furthermore, spatial risk area identification was carried out for the DM death events [11], in order to detect clusters in space. At this stage, the SaTScan software version 9.6 was used on Poisson discreet model, and only using the urban census sectors, because they showed all DM mortality cases included in the period of this study. It was set the following conditions: no geographical overlap on the clusters, the cluster maximum size equal to $50 \%$ from the population exposed, the circular shape cluster, and 999 repetitions.

A sweep scan analysis showed the high and low risks of a cluster to appear by using the relative risk (RR), which makes the area comparison possible since these are standardized in such a way, that can wear off the effect on the varied population. It was set up an error type I of $5 \%$ ( $P$-value <0.05) as statistically considerable clusters and finally, the $95 \%$ confidence interval [11]. From this step on, it was drowned 
Citation: Silva AJL, Istilli PT, Teixeira CRS, Lima RAD, Pereira MCA, Damasceno MMC, Garcia RAC, Calixto AAS. Income-Related Mortality by Diabetes Mellitus. Diab Res Open Access. 2020 Aug 22;2(2):56-63.

\section{Original Article}

thematic maps with associated risks by using the QGIS Desktop software version 2.18.

The analysis of spatial relation, between income and DM mortality, was drawn on the Paulista Social Vulnerability Index from the Foundation State System of Data Analysis, using the following income stratification: proportion of Households with no income per Capita; Proportion of Households with Income per capita up to $1 / 8$ minimum wage; proportion of households with income per capita from $1 / 8$ to $1 / 2$ minimum wage; proportion of households with income per capita from $1 / 2$ to 2 minimum wage; proportion of households with income per capita over 2 minimum wage [12].

For this matter, a calculation and standardization of DM mortality rate was performed for each census sector, and furthermore, it was checked the spatial correlation by using Bivariate Local Moran's I between these two variables (income and mortality rate), by using the GeoDa software version 1.12, which points to linear association level (positive or negative), between the value to a variable in some location I, and the other variable average in close locations [13]. This statistic may vary from -1 to 1 , where values close to 0 , indicate no significant spatial correlation, and values close to one indicates a spatial bound between the studied variables [13].

This study was approved by the Ethics Committee of the Nursing College of the University of Sao Paulo at Ribeirao Preto, process $n^{0} 3.260 .775$, with the agreement of Municipal Health Department from Ribeirao Preto, SP, Brazil.

\section{Results}

From 2010 to 2014, there were 583 deaths by DM, emphasizing a higher number of deaths on female sex (55.06\%) and an increase of $25.53 \%$ from the first to the last year (Table-1).

It was proven a negative spatial relation between the incomes of up to two minimum wages per capita and age-standardized mortality rate by age (ASMR). $\mathrm{I}=-0.13$ (Table-2).

Table-1: Distribution of the absolute number (n) and percentage (\%) of deaths on residents of Ribeirao Preto by diabetes mellitus, according to sex and year.

\begin{tabular}{|r|c|c|c|c|c|c|}
\hline Year & Male & \% & Female & \% & Total & \% \\
\hline $\mathbf{2 0 1 0}$ & 47 & 8.06 & 57 & 9.78 & 104 & 17.84 \\
\hline $\mathbf{2 0 1 1}$ & 51 & 8.75 & 46 & 7.89 & 97 & 16.64 \\
\hline $\mathbf{2 0 1 2}$ & 54 & 9.26 & 69 & 11.84 & 123 & 21.1 \\
\hline $\mathbf{2 0 1 3}$ & 51 & 8.75 & 63 & 10.81 & 114 & 19.55 \\
\hline $\mathbf{2 0 1 4}$ & 59 & 10.12 & 86 & 14.75 & 145 & 24.87 \\
\hline Total & 262 & 44.94 & 321 & 55.06 & 583 & 100 \\
\hline
\end{tabular}

Table-2: Bivariate Local Moran's I between diabetes mellitus mortality rates and income variables.

\begin{tabular}{|l|c|c|}
\hline \multicolumn{1}{|c|}{ Variables } & $\mathbf{I}^{\mathbf{a}}$ & P-value $^{\mathbf{b}}$ \\
\hline Proportion of households with no income per capita & 0 & 0.351 \\
\hline Proportion of households with income per capita up to 1/8 minimum wage & 0.04 & $0.016^{*}$ \\
\hline Proportion of households with income per capita from 1/8 to 1/2 minimum wage & 0.06 & $0.001^{*}$ \\
\hline Proportion of households with Income per capita from 1/2 to 2 minimum wage & 0.12 & $0.001^{*}$ \\
\hline Proportion of households with income per capita over 2 minimum wage & -0.13 & $0.001^{*}$ \\
\hline \multicolumn{2}{|c|}{ a = Bivariate Local Moran's I ; b=P-value < 0.05 } & \\
\hline
\end{tabular}


Citation: Silva AJL, Istilli PT, Teixeira CRS, Lima RAD, Pereira MCA, Damasceno MMC, Garcia RAC, Calixto AAS. Income-Related Mortality by Diabetes Mellitus. Diab Res Open Access. 2020 Aug 22;2(2):56-63.

\section{Original Article}

Regarding mortality by DM in both sexes, it was noted three spatial clusters, one of protection, including 178 census sectors on a population of 104.832 inhabitants, ASMR=8.4/100.000 inhabitants and $\mathrm{RR}=0.39(95 \% \mathrm{CI}=0.29-0.54)$ and another two of high-risk, one of them, including 280 census sectors on a population of 150.998 inhabitants, ASMR= 32.2/100.0oo inhabitants and $\mathrm{RR}=2.21(95 \% \mathrm{CI}=1.88$ 2.61) and another one, including 1 census sector on a population of 67 inhabitants $\mathrm{ASMR}=1.202 .3 / 100.000$ inhabitants and $\mathrm{RR}=63.83 \quad(95 \% \mathrm{CI}=24.43-164.56)$ (Fig-1).

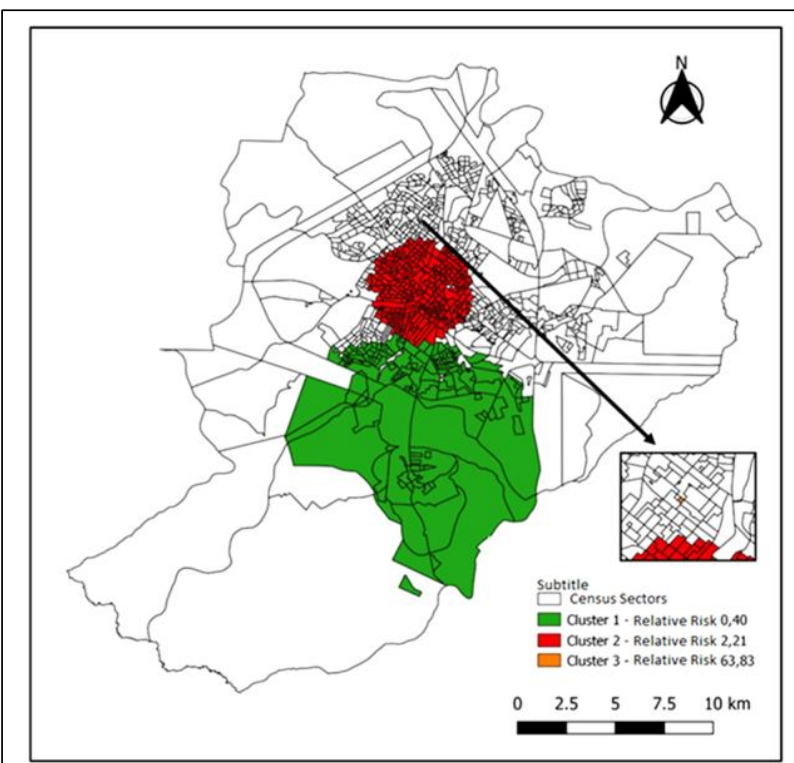

Fig-1: Mortality by diabetes mellitus spatial clusters from 2010 to 2014.

Regarding male sex, it was noted two protection spatial clusters for the deaths by DM to happen, one including 54 census sectors, the population of 18.477 inhabitants ASMR=2.2/100.000 inhabitants and $\mathrm{RR}=0.11(95 \% \mathrm{CI}=0.03-0.46)$ and another one, including 178 census sectors, the population of 50.673 inhabitants, $A S M R=7.9 / 100.000$ inhabitants and $\mathrm{RR}=0.40 \quad(95 \% \mathrm{CI}=0.25-0.63)$. It was, also, noted a high-risk spatial cluster for the deaths by DM to happen with 348 census sectors, population 88.557 inhabitants, $\mathrm{ASMR}=30.5 / 100.000$ inhabitants and $\mathrm{RR}=2.48(95 \% \mathrm{CI}=1.94-3.16)($ Fig-2 $)$. 


\section{Discussion}

It was found, in the municipality of Ribeirao Preto, SP, Brazil, from 2010 to 2014, a total of 583 deaths by DM, an increase of $25.53 \%$ from the first to the last year of study. It highlights a major occurrence of deaths by DM in the female population (55.06\%). A Brazilian study came out with evidence, by analyzing the occurrence, prevalence, and mortality by DM, ranging from 1990 to 2015, showing, as above, the same major occurrence of mortality by DM in female sex $(56.10 \%)$, and an increase in the gross mortality rate of $90 \%$ from the first to the last year of study [14].

A study in the United Kingdom examined the occurrence, prevalence, and mortality by DM over a period of 11 years, from 2004 to 2014, and it was found a higher occurrence and prevalence rate of DM in males, highlighting, that the prevalence rate in 16-34 age group nearly doubled in females, from 10.56 to 20.85 per 10.000 inhabitants, whereas, in males, there was a smaller increase of 10.11 to 16.11 per 10.000 inhabitants [15]. On the other hand, the same study found an overall decrease in mortality rate by DM of 47.6o during the study, observing a higher risk in females than in males, which matches our study [15].

Another study in Ghana examined the occurrence, prevalence, and mortality in hospitalized diabetic patients from 1983 to 2013 , they found an increase of $633 \%$ in diabetes-related admissions from the first to the last year of study, a greater proportion (57.14\%) in females admissions, mostly elderly, than in males and an overall increase of 74.66 hospital mortality rate by DM [4].

However, despite the male population has a lower occurrence and prevalence of DM, they, maybe, premature dying from DM acute complications, other diseases, and non-communicable diseases complications, especially external causes, in contrast to the female population, which has a higher life expectancy, that is, higher exposure to CNCDs, so this leads to a higher level of mortality by DM by the end of their old age, especially, by chronic diseases complications [16], as it may be noted in the same scenario and period study like this one, which found
231 premature deaths by DM, 130 (56.28\%) in males and 101 (43.72\%) in female [17] and in another study, also, at the same period and scenario as this one, it was found 348 deaths in elderly up to 70 years old, 218 $(62.64 \%)$ in female and $130(37.36 \%)$ in male [18].

It was shown a negative spatial correlation related to income (proportion of households with income per capita up to 2 minimum wage) meaning a lower occurrence of mortality by DM related to a higher income. A study in Sweden found that low-income population has the doubled odds of dying than the high-income population [19], another 2018 study in South Korea, found that DM diagnosed groups have a higher mortality rate as their income gets lower [20]. On the other hand, a study in Canada, from 1994 to 2005, found a DM mortality decrease of $36 \%$ for high income and 31\% for the low-income population [21].

It was ratified by literature that low-income individuals have a twice higher risk of having a harmful standing lifestyle, like inactivity, smoking habits, which may cause the progression of the disease and mortality by DM [22].

There are, also, evidence of a higher prevalence of DM in low-income individuals with shorter schooling, causing a level decrease of knowledge than in highincome individuals with a higher schooling level [23], and consequently, it gets harder to obtain the knowledge about the changes needed by DM, especially concerning a healthier lifestyle and the handling of the devices needed on the treatment of this CNCD [24].

Regarding the statistics sweep of spatial clusters results, it can be found protection and risk areas for the DM mortality to occur at the study site. It is important to highlight that, as in either sexes analysis as in separate by male or female, the south zone was taken as a protected area. Therefore, the marked risk areas fill the census sectors in the center, west, and north region of the municipality. The Paulista Social Vulnerability Index data shows that the proportion of households with income per capita from $1 / 8$ to $1 / 2$ minimum wage inside the risk region is bigger than in the protection region, the risk area ranged from 1.6\% to $64.8 \%$ [12]. 
Such findings may infer some social inequality related to DM mortality cause in the municipality of this study, once the south region has better living conditions, such as outdoor recreation, afforestation, higher income per capita and a higher schooling level [25]. The factors leading to a positive health/sickness process, for the population in vulnerable areas of the city, are highlighted in the risk cluster section in this study.

It is pointed out the national economic growth in the municipality in this study, especially from 2016 to 2017, for representing the third biggest Brazil gross domestic product gains, leading to an opportunity for the weakest region population of the country to have a better life, triggering a fast and disorganized urban growth [25], so this could, probably, limit these new habitants at the weakest geographic regions of the city, and consequently, a more restrictive lifestyle for healthier options.

In this context, it is pointed out that DM affects all socio-economic groups, in different ways though, since there are social mismatches, more than single choices, they are major responsible for the occurrence, prevalence, and mortality by DM [26].

It is questioned, so, the onus caused by DM on the needy population when it comes to disease treatment and care, and, what is the solution for the primary health care on preventive actions and health development in order to reduce its occurrence, prevalence, and mortality.

In spite of having a free and universal health service in Brazil, which makes sure on keeping the treatment supplies and life quality provision, the patient usually has to run over the family's income to fulfill the treatment expenses, as for healthier life habits, especially, to feed themselves and practice physical activities [27,28].

Another relevant aspect is the world health managers' perception, either national or local, on the burden of the DM and other CNCDs, on the one hand, DM may cause a significant number of deaths and has a socio-economic negative impact for the carrier and their families, the municipality, the state and country as it is evidenced in other studies $[4,14,15,17,18]$, on the other hand, there is a minimal investment in order to face this and others CNCDs, they get only $2 \%$ in the allocation of resources, while other communicable diseases, such as HIV, tuberculosis, and malaria get $36 \%$ of health allocation resources [7].

It is mentioned, as an example, the current pandemic situation by COVID-19, an infectious disease which increases, significantly, the admissions in hospitals and mortality for DM carriers [29,30,31]. For now, there have been performed international and national researchers and investments for health, related to COVID-19, it is suggested that this infectious disease could have a softer impact if there was the same effort and investments for the CNCDs in the previous year's [7].

Consequently, this study provides subsidies for management and allocation of resources in weaker pointed areas for mortality by DM and a deep reflection on future strategies for health education, focused on a higher level of knowledge for the lowincome population about the risk factors for the development of DM and its complications. In addition to the affordable alternatives, it guaranties the treatment admission and a healthier lifestyle adoption, according to the current principles and guidelines of the National Health Promotion Policy [32].

Among limitations of this study, it stands out the impossibility of stratifying the type of DM, in order to list which one has a higher relation to low-income. The need for collecting the DM mortality data in the Epidemiological Surveillance Division from Municipal Health Department of Ribeirao Preto, in order to perform the spatial analysis matches another limitation, thus during the pickup, there were only 2010-2014 data, so, this prevented a greater period of time to be evaluated.

\section{Conclusions}

Mortality by DM is in a greater proportion of females and in households with income lower than 2 minimum wages. The south region was identified as a protection area for the occurrence of mortality by DM, while the central, north, and west regions were 
Citation: Silva AJL, Istilli PT, Teixeira CRS, Lima RAD, Pereira MCA, Damasceno MMC, Garcia RAC, Calixto AAS. Income-Related Mortality by Diabetes Mellitus. Diab Res Open Access. 2020 Aug 22;2(2):56-63.

Original Article

identified as risk areas for the occurrence of mortality due to their higher social vulnerability. It is hoped that the evident results in this study may foster and guide the prevention strategies and health development for the low-income population and residents in the risk areas.

\section{Funding}

National Council for Scientific and Technological Development (CNPq)

\section{Conflict of Interest}

All authors have read and approved the final version of the manuscript. The authors have no conflicts of interest to declare.

\section{References}

[1] World Health Organization. Global report on diabetes. Geneva: WHO; 2016. [Cited 2020 Mar 29]. Available from:

http://apps.who.int/iris/bitstream/handle/10665/204 871/9789241565257_eng.pdf;jsessionid=814AB1D426D 423740A961B225CFA8oog? sequence $=1$

[2] Sociedade Brasileira de Diabetes. Diretrizes da Sociedade Brasileira de Diabetes: 2019-2020. São Paulo: Clannad Editora científica; 2019. [Cited 2020 Mar 29]. Available from:

https://www.diabetes.org.br/profissionais/images/DI RETRIZES-COMPLETA-2019-2020.pdf

[3] International Diabetes Federation. Diabetes Atlas. 8th ed; 2019. Available from:

http://www.diabetesatlas.org/

[4] Sarfo-Kantanka O, Sarfo FS, Oparebea Ansah E, Eghan B, Ayisi-Boateng NK, Acheamfour-Akowuah E. Secular Trends in Admissions and Mortality Rates from Diabetes Mellitus in the Central Belt of Ghana: A 31-Year Review. PLoS One. 2016 Nov 22;11(11):e0165905. [PMID: 27875539]

[5] Ministério da Saúde (BR). Secretaria de Atenção à Saúde. Departamento de Atenção Básica. Estratégias para o cuidado da pessoa com doença crônica. Brasília: Ministério da Saúde; 2014. (Cadernos de Atenção Básica, 38). [Cited 2020 Mar 29]. Available from: http://conitec.gov.br/images/pdf/Caderno_AtencaoBa sica35.pdf

[6] Cockerham WC, Hamby BW, Oates GR. The Social Determinants of Chronic Disease. Am J Prev Med. 2017
Feb;52(1S1):S5-12. [PMID: 27989293]

[7] Hatefi A, Allen LN, Bollyky TJ, Roache SA, Nugent R. Global susceptibility and response to noncommunicable diseases. Bull World Health Organ. 2018 Aug;96(8):586-88. [PMID: 3010480o]

[8] Medronho RA, Bloch KV, Luiz RR, Werneck GL (eds). Epidemiologia, 2rd ed. São Paulo: Atheneu; 2009.

[9] Instituto Brasileiro de Geografia e Estatística. Censo 2010. Rio de Janeiro: IBGE; 2010 [Cited 2020 Apr 12]. Available from:

https://censo2010.ibge.gov.br/

[10] World Health Organization. Global status report on noncommunicable diseases 2014. Geneva: WHO; 2014 [Cited 2020 Apr 12]. Available from:

http://www.who.int/nmh/publications/ncd-status-

report-2014/en/

[11] Kulldorff M, Nagarwalla N. Spatial disease clusters: detection and inference. Stat Med. 1995 Apr;14(8):799-10. [PMID: 764486o]

[12] Fundação Seade. Índice paulista de vulnerabilidade social do município de Ribeirão Preto. São Paulo; 2010 [Cited 2020 Apr 13]. Available from: http://indices-

ilp.al.sp.gov.br/view/pdf/ipvs/mun3543402.pdf.

[13] Anselin L. Local indicators of spatial association LISA. Geographical Analysis. 1995 Apr;27(2):93-115.

[14] Duncan BB, Schmidt MI, Ewerton Cousin, MoradiLakeh M, Passos VMA, França EB, Marinho F, Mokdad $\mathrm{AH}$. The burden of diabetes and hyperglycemia in Brazil-past and present: findings from the Global Burden of Disease Study 2015. Diabetol Metab Syndr. 2017 Mar 14;9:18. [PMID: 28293304]

[15] Zghebi SS, Steinke DT, Carr MJ, Rutter MK, Emsley RA, Ashcroft DM. Examining trends in type 2 diabetes incidence, prevalence and mortality in the UK between 2004 and 2014. Diabetes Obes Metab. 2017 Nov;19(11):1537-45. [PMID: 28387052]

[16] Siviero PCL, Souza LG, Machado CJ. Sex mortality differentials in São Paulo in 2005 and 2016: contribution of age groups and main causes of death. Rev Bras Estud Popul. 2019 Dec;36:eoog9.

[17] Istilli PT, Teixeira CRS, Zanetti ML, Lima RAD, Pereira MCA, Ricci WZ. Assessment of premature mortality for noncommunicable diseases. Rev Bras Enferm. 2020 Mar;73(2):e20180440. [PMID: 32159691] 
Citation: Silva AJL, Istilli PT, Teixeira CRS, Lima RAD, Pereira MCA, Damasceno MMC, Garcia RAC, Calixto AAS. Income-Related Mortality by Diabetes Mellitus. Diab Res Open Access. 2020 Aug 22;2(2):56-63.

\section{Original Article}

[18] Lima RAD, Istilli PT, Teixeira CRS, Zanetti ML, Torquato MTDCG. Diabetes mellitus mortality in a municipality in the state of São Paulo, 2010 to 2014. Rev Saude Publica. 2019 Feb 25;53:24. [PMID: 30810661]

[19] Rawshani A, Svensson AM, Zethelius B, Eliasson B, Rosengren A, Gudbjörnsdottir S. Association Between Socioeconomic Status and Mortality, Cardiovascular Disease, and Cancer in Patients With Type 2 Diabetes. JAMA Intern Med. 2016 Aug 1;176(8):1146-54. [PMID: 27367969]

[20] Shin WY, Kim HC, Lee T, Jeon DH, Ha KH, Kim DJ, Chang HJ. Combined effects of diabetes and low household income on mortality: a 12-year follow-up study of 505677 Korean adults. Diabet Med. 2018 Oct;35(10):1345-54. [PMID: 29851428]

[21] Lipscombe LL, Austin PC, Manuel DG, Shah BR, Hux JE, Booth GL. Income-related differences in mortality among people with diabetes mellitus. CMAJ. 2010 Jan 12;182(1):E1-17. [PMID: 20026629]

[22] Jarvandi S, Yan Y, Schootman M. Income disparity and risk of death: the importance of health behaviors and other mediating factors. PLoS One. 2012;7(11):e49929. [PMID: 23185488]

[23] Hosseini Z, Whiting SJ, Vatanparast H. Type 2 diabetes prevalence among Canadian adults - dietary habits and sociodemographic risk factors. Appl Physiol Nutr Metab. 2019 Oct;44(10):1099-104. [PMID: 31386561]

[24] Moura KL, Catão CDS, Lima RA, Cruz JB. Lifestyle and self-perceived health in the control of type 2 Diabetes Mellitus. Rev Cienc Med Biol. 2019 Apr;18(1):52-6o.

[25] Prefeitura Municipal de Ribeirão Preto (SP). Secretaria do Planejamento e Gestão Pública. Revisão da lei de parcelamento, uso e ocupação do solo: produto 3 - diagnóstico socioeconômico. Ribeirão Preto: Secretaria do Planejamento e Gestão Pública;
2019 [Cited 2020 Jun 25]. Available from: https://www.ribeiraopreto.sp.gov.br/files/splan/plano d/solo-produto-3.pdf

[26] Instituto Brasileiro de Geografia e Estatística. Produto Interno Bruto dos Municípios 2017. Rio de Janeiro: IBGE; 2019 [Cited 2020 Jun 25]. Available from:

https://biblioteca.ibge.gov.br/visualizacao/livros/liv1o 1688_informativo.pdf

[27] Orozco LB, Alves SHS. Differences of self-care among patients with diabetes mellitus type 1 and 2 . Psic Saude Doenças. 2017 Apr;18(1):234-47.

[28] Andrade MV, Noronha KVMS, Menezes RM, Souza MN, Reis CB, Martins DR, Gomes L.. Socioeconomic inequality in access to health services in Brazil : a comparative study between Brazilian regions in 1998 and 2008. Econ Apl. 2013 Dec;17(4):623-45.

[29] Muniyappa R, Gubbi S. COVID-19 pandemic, coronaviruses, and diabetes mellitus. Am J Physiol Endocrinol Metab. 2020 May 1;318(5):E736-41. [PMID: 32228322]

[30] Hussain A, Bhowmik B, do Vale Moreira NC. COVID-19 and diabetes: Knowledge in progress. Diabetes Res Clin Pract. 2020 Apr;162:108142. [PMID: 32278764]

[31] Zhou F, Yu T, Du R, Fan G, Liu Y, Liu Z, Xiang J, Wang Y, Song B, Gu X, Guan L, Wei Y, Li H, Wu X, Xu J, Tu S, Zhang Y, Chen H, Cao B. Clinical course and risk factors for mortality of adult inpatients with COVID-19 in Wuhan, China: a retrospective cohort study. Lancet. 2020 Mar 28;395(10229):1054-62. [PMID: 32171076]

[32] Malta DC, Morais OL Neto, Silva MM, Rocha D, Castro AM, Reis AA, Akerman M. National Health Promotion Policy (PNPS): chapters of a journey still under construction. Cien Saude Colet. 2016 Jun;21(6):1683-94. [PMID: 27281656] 